\title{
THE ROLE OF QUALITY IN BUSINESS MANAGEMENT
}

\author{
[Role kvality v podnikovém řízení] \\ Zdeněk Hruška $^{1}$, Marcela Ježková ${ }^{2}$, Jana Hinke ${ }^{3}$ \\ ${ }^{I}$ Západočeská univerzita v Plzni, Fakulta ekonomická, Husova 11, 30614 Plzeň \\ Email: hruskaz@kfu.zcu.cz. \\ ${ }^{2}$ KS-Europe s.r.o., Komenského 598, 33203 Štáhlavy \\ Email:jezkova.mar@seznam.cz \\ ${ }^{3}$ Západočeská univerzita v Plzni, Fakulta ekonomická, Husova 11, 30614 Plzen̆ \\ Email: hinke@kfu.zcu.cz
}

\begin{abstract}
The paper describes the current issue of the quality management in the corporate sector. The focus is placed on medium and large companies, because these companies lead to the creation of the post of the quality managers. The quality should be incorporated in the corporate strategy. These companies should successfully manage the quality of their products, services, business processes and other aspects of the quality. It requires the monitoring and the analyzing the cost of the quality. Attention should be paid to the quality because of its direct impact on the customer loyalty. The quality control can be based on 8 quality management principles whose respect greatly contributes to the increasing the efficiency of company operations. The paper contains results of the research in 60 mainly large companies. This research revealed that the most prominent problem of the quality control is the fluctuacion of employee and insufficient the record keeping of the quality cost.
\end{abstract}

Keywords: cost of quality, effectiveness, fluctuation, principles of quality management, quality.

JEL classification: M11, M21

Doručeno redakci: 17.2.2016; Recenzováno: 23.2.2016; 1.3.2016; Schváleno k publikování: 26.5.2016

\section{Úvod}

Samozřejmostí pro současné podnikatelské strategie je úzké provázání finanční analýzy podniku a vytváření hodnoty pro zákazníka. Sleduje se korelace kvality na ekonomickou výkonnost podniku při aplikaci řady ekonomických ukazatelů. Pro sledování kvality jsou v praxi kvantifikovány zvlášs' ekonomické ukazatele a zvláśs' ukazatele kvality. V ekonomických ukazatelích jsou zohledněny zisk, náklady, které jsou vynakládány, růst produktivity práce a celá řada dalších ekonomických ukazatelů. U ukazatelů kvality se sleduje počet diferencí ve výrobě, počet reklamací a spokojenost zákazníků. Poskytování prvotřídní kvality je elementárním východiskem získání a udržení loajálního zákazníka. Rozhodujícími faktory současné a budoucí př́znnivé ekonomické výkonnosti podniku je kvalita výrobků a služeb, kvalita procesů, kvalita péče nejen o zákazníky, ale i o zaměstnance a o životní prostředí. (Plášková, 2004) Záměrem tohoto článku je zdůraznit atributy kvality v podnikovém řízení a přínos kvality pro rozvoj podniku.

V literatuře je kvalita definována jako „stupeň splnění požadavků souborem inherentních charakteristik.“ (Hoyle, 2009, s. 24) Požadavek je vymezen jako potřeba nebo očekávání, které se předpokládají nebo jsou závazné. Inherentní jako existující v něčem, zejména jako trvalá charakteristika. (Veber, 2010) Kvalita je základním faktorem podniku napomáhající při získávání a udržování zákazníků. Podnik klade důraz na kvalitu především z důvodu, že kvalita přispívá k finanční výkonnosti podniku. (Štamfestová, 2013) Vysoká orientace na zákazníka a stoupající závislost produkti̊ a služeb posunují otázky kvality stále více do popředí zájmu podniků. Zásadními faktory úspěchu podniku jsou kritéria kvalita, cena a dodací termíny. (Linß, 2011) Úroveň kvality je dána úrovní spokojenosti zákazníka. 
Spokojenost zákazníka rovněž odráží hodnotu, kterou zákazník produktu přisuzuje a náklady, které je ochoten na produkt vynaložit. (Suchánek, 2014)

Fungování systému kvality v podniku vyžaduje podporu a zapojení vrcholového vedení. Musí rozhodnout o implementaci systému managementu kvality a důsledně podporovat tento systém. (Veber, 2010) Moderní management se orientuje na tři základní faktory, tzv. kritické faktory úspěšnosti, kterými jsou kvalita, čas a náklady. (Nenadál, 2008) V dř́ve platných normách ISO (International Organization for Standardization), které se týkaly managementu jakosti, byl kladen důraz především na procesy a jejich dokumentaci. Lidskému faktoru se více věnuje systém TQM (Total Quality Management), který upozorňuje na skutečnost, že postoje a chování zaměstnanců do značné míry určují výkonnost podniku. Proto je důležitá i motivace zaměstnanců. Nové vydání norem ISO v roce 2000 již také klade důraz na lidský faktor v osmi zásadách managementu jakosti. (Nenadál, 2004)

Koordinací a řízením kvality napříč celým podnikem je odpovědný manažer kvality. Jeho odpovědností je zejména implementace politiky jakosti a dosažení stanovených cílů kvality v podniku. Je odpovědný za kvalitu ve všech jejích fázích - definuje strategii kvality, měří kvalitu, analyzuje, zpracovává plány kvality, řídí a monitoruje dosažení cílů kvality, podporuje požadavky zákazníků, je odpovědný za návrhy zlepšování systému řízení kvality. (ManagementMania, 2011-2013) Manažer kvality musí zároveň přesvědčit vrcholové vedení o faktu, že kvalita významnou měrou přispívá $\mathrm{k}$ prŕínivým ekonomickým výsledkům podniku. (Plášková, 2004) Součástí firemní strategie se musí stát zainteresovanost na kvalitě. Pro úspěšné vedení a fungování podniku je důležité, aby kvalita byla řízena systematickým a jasným způsobem. Př́spěvek poukazuje na potenciální náklady na kvalitu v podniku a zásady managementu kvality na bázi sekundárního a primárního výzkumu. Záměrem článku je zdůraznit atributy kvality na řízení a rozvoj podniků.

\section{Potenciální náklady na kvalitu v podniku}

Náklady na nízkou kvalitu, které byly explicitně kvantifikovány, prošly účetní evidencí, jsou vrcholovým managementem podniku evaluovány. Jedná se o ztráty z vadných výrobků, reklamace, zaviněné škody na životním prostředí, zdraví a bezpečnosti. Účetní evidence ovšem nezachytí všechny ztráty, ke kterým v podniku dojde. Náklady na nízkou kvalitu, které neprošly účetní evidencí, je potřeba vyhledávat, evidovat a kvantifikovat v operativní evidenci nákladů na kvalitu. Podnik často nemá o výši těchto nákladů přehled, je ale potřeba je explicitně vymezit, eliminovat a př́ípadně minimalizovat. Jedná se o náklady na prostoje, neefektivní využívání zdrojů, nápravy neshod (za neshodu je považována chybovost neboli produkce vadných výrobků nebo výrobků se sníženou kvalitou), zaškolování pracovníků, nepružnost v podnikových procesech, fluktuace pracovníků. (Zvoneček, 2001) Na základě metodiky Lean production uspokojující požadavky zákazníka v co nejkratší době s co nejnižšími náklady při dodržení požadované kvality je nejpodstatnější odstranit neefektivní využívání zdrojů ve všech procesech a to zejména u těch, které přidávají produktu hodnotu. (Jáč, 2013)

V operativní evidenci nákladů na kvalitu by měly být zachyceny všechny náklady, ke kterým $\mathrm{v}$ podniku došlo, ale které nebyly $\mathrm{v}$ účetnictví podniku zachyceny. Většinou se skrývají v položce režijní náklady. Pokud podnik bude tyto náklady kvantifikovat a prrípadně sledovat jejich vývoj, trendy a příčiny jejich vzniku, může $\mathrm{v}$ budoucnu na tyto ztráty explicitně reagovat a eliminovat je. V koherenci s kvalitou se jedná o náklady na fluktuaci zaměstnanců, zaškolování pracovníků, náklady na neshody a prevenci, prostoje, ztráty z nadměrných kapacit, plýtvání, nápravy neshod, chybná rozhodnutí, změny výrobních postupů či dokumentace, zbytečná administrativa, nadměrné zásoby.

Fluktuace je přirozený koloběh zaměstnanců mezi podniky a mezi výběrem pracovních nabídek. Doporučovaná hodnota míry fluktuace je 5 - $10 \%$, někteří odborníci doporučují 
udržovat úroveň celkové roční míry fluktuace mezi $5-7 \%$. Vysoká míra fluktuace sebou přináší pro podnik vysoké náklady, které je potřeba sledovat. Ve spojení s kvalitou je nutné kvantifikovat náklady na přesčasy stávajících zaměstnanců, na najmutí dočasné pracovní síly, na investice do vzdělávání a školení zaměstnance, na ověřování a testování nových uchazečů, zaškolování na pracovišti a materiál potřebný na zaškolení. (Duda, 2014) Fluktuace je s kvalitou velmi úzce spojena. Neustálé zaškolování nových pracovníků sebou nese velké riziko snížení kvality výrobků. V největší míře se to projeví u zvýšené fluktuace zejména v období zaškolování a snížené produktivity zaměstnance a u nakupované dočasné pracovní síly. Pokud zaměstnanci odchází zejména během této fáze, znamená to pro podnik velké množství neustále nových nezaučených lidí. Ve sledovaných podnicích bylo vlivem vysoké roční míry fluktuace evaluováno zhoršení kvóty kvality a bylo zaznamenáno dokonce zhoršení i o více než $90 \%$.

K měření a monitorování nákladů vztahujících se ke kvalitě je možno využít některé základní modely uvedené v tabulce 1 , kde jsou kompilovány i základní odlišnosti těchto modelů.

Tabulka 1: Modely finančního měření v systémech managementu kvality

\begin{tabular}{|c|c|c|c|c|}
\hline Skupina nákladů & $\begin{array}{c}\text { Model } \\
\text { PAF }\end{array}$ & $\begin{array}{c}\text { Model } \\
\text { COPQ }\end{array}$ & $\begin{array}{c}\text { Model procesních } \\
\text { nákladů }\end{array}$ & $\begin{array}{c}\text { Model výdajů } \\
\text { na životní cyklus }\end{array}$ \\
\hline Náklady na interní vady & $\mathrm{X}$ & $\mathrm{X}$ & $\mathrm{X}$ & $\mathrm{X}$ \\
\hline Náklady na externí vady & $\mathrm{X}$ & $\mathrm{X}$ & $\mathrm{X}$ & $\mathrm{X}$ \\
\hline Náklady na hodnocení & $\mathrm{X}$ & & $\mathrm{X}$ & $\mathrm{X}$ \\
\hline Náklady na prevenci & $\mathrm{X}$ & & $\mathrm{X}$ & $\mathrm{X}$ \\
\hline Promrhané př́ležitosti a investice & & $\mathrm{X}$ & $\mathrm{X}$ & \\
\hline Náklady na škody na prostředí & & $\mathrm{X}$ & & $\mathrm{X}$ \\
\hline Náklady vztahující se ke kvalitě u uživatele & & & & \\
\hline
\end{tabular}

Zdroj: vlastní zpracování dle Nenadál (2004)

Náklady na interní vady jsou náklady vznikající uvnitř podniku v důsledku vad při plnění požadavků na kvalitu a legislativu. Jedná se o:

- Náklady na neshody vzniklé při výrobě. Naprríklad ztráty z neopravitelných vad a jejich likvidace, ztráty $\mathrm{z}$ oprav, náklady na znehodnocení materiálu a skladových zásob, náklady na zvýšenou kontrolu ověřování shody.

- Náklady, které se vztahují k jakosti dodávek. Jedná se o náklady na neshody dodaného materiálu zjištěné až po přijetí v podniku.

- Náklady na neshody návrhu a vývoje, tj. na opravy dokumentace, přezkoumání a ověření návrhu.

- Další náklady na interní neshody. Může jít o náklady na analýzu příčin vzniku neshod, ztráty způsobené nižší výkonností, ztráty na majetku zákazníka.

Náklady na externí vady jsou náklady vzniklé v důsledku neplnění požadavků zákazníků a legislativy po dodání zákazníkovi. Jedná se o:

- Náklady v reciprocitě k nespokojenosti zákazníka. Jsou to náklady na reklamace, na záruční servis, na skladování a expedici náhradních dílů, na prohrané soudní spory, na odstraňování škod.

- Náklady z důvodu ztracených příležitostí. Např́klad náklady na slevy z cen výrobků, ztráty stahováním vadných výrobků z trhu.

Náklady na externí vady by podniky měly kvantifikovat. Zvyšování těchto nákladů může velmi negativně ovlivnit ekonomické výsledky podniku. Tyto náklady mohou být v některých případech pro podnik až likvidační.

Náklady na hodnocení jsou náklady ve spojitosti s procesy posuzování a prokazování shody na straně výrobce. Jde o náklady na: 
- Interní procesy posuzování shody, například náklady na vstupní, interní a výstupní kontrolu, na přezkoumání dokumentace, na inovaci programů na měření a vyhodnocení dat, na provoz měrových středisek.

- Externí procesy posuzování shody, např́iklad náklady na certifikaci, schvalování výrobku, získání české značky shody nebo značky CE.

- Nákup a údržbu měřících zařízení. Jedná se o náklady na kalibraci měřidel, na údržbu měřících zařízení.

- Přezkoumání záznamů o hodnocení, tj. rozbor a vyhodnocování výsledků měření.

- Další náklady na hodnocení. Jedná se naprríklad o náklady na marketingové testy, výrobu vzorků, posuzování způsobilosti strojů a procesů.

Náklady na prevenci jsou náklady na předcházení a restrikci rizika výskytu neshody a rovněž náklady na zlepšování. Jedná se o:

- Náklady v korelaci k rozvoji vztahů se zákazníky, např́íklad na vznik zákaznických středisek, na průzkum trhu a definování požadavků na výrobky.

- Náklady na management kvality dodávek. Jde o náklady na rozvoj vztahů s dodavateli, na pomoc dodavatelům a na společné projekty zlepšování a motivaci dodavatelů.

- Náklady na organizaci a správu managementu kvalitu jsou náklady na dokumentaci, na informační systémy, na útvar řízení kvality.

- Náklady na procesy zlepšování zahrnují náklady na výzkum a vývoj, na opatření k nápravě, na preventivní opatření.

- Náklady preventivní povahy mohou zahrnovat náklady na činnost externích poradenských firem, na výcvik, vzdělávání, na realizaci motivačních programů.

Promrhané př́iležitosti jsou zbytečné náklady podniku $\mathrm{v}$ důsledku špatných rozhodnutí řídících pracovníků. Jejich kvantifikace a identifikace je velmi obtížná. Jsou to náklady $\mathrm{v}$ koherenci $\mathrm{k}$ nedokončeným projektům, nepotřebným zásobám, plýtvání, nevyužitým kapacitám, prostojům, nevyužitým plochám hal a skladů.

Náklady na škody na prostř̌edí vznikají v koherenci s nedodržováním požadavků na životní prostředí. Jedná se o náklady $\mathrm{v}$ souvislosti s likvidací odpadů, recyklací, pokutami za poškozování prostředí, na eliminaci znečištování ovzduší nebo na léčení chorob z povolání.

Náklady vztahující se ke kvalitě u uživatele jsou celkové náklady uživatele na provoz, údržbu a likvidaci zařízení. Jedná se o náklady na výcvik obsluhy, na nákup nářadí, na mzdu obsluhy, na odpisy, na údržbu a opravy zařízení. (Nenadál, 2004)

Při kvantifikaci nákladů vztahujících se ke kvalitě je důležité explicitně určit, co vše tyto náklady $\mathrm{v}$ podmínkách daného podniku tvoří, $\mathrm{k}$ čemuž slouží $\mathrm{k}$ tomu určené modely. Je rovněž potřeba rozhodnout, který model měření bude pro daný náklad nejvhodnější. Je možné použít i kombinaci modelů.

Model PAF je nejrozšířenějším modelem pro měření nákladů vztahujících se ke kvalitě. Základem je explicitní definování všech činností, které je potřeba v souvislosti s náklady na kvalitu vyčíslit a rozhodnout, která činnost je nákladem na kvalitu a která ne. Tyto údaje pak slouží podniku nejen ke sledování vývoje těchto nákladů, ale i k efektivnímu rozhodování managementu. Nevýhodou je nemožnost srovnání s jinými podniky. Model COPQ vychází z předpokladu, že neplnění požadavků na kvalitu způsobuje podniku nezanedbatelné ztráty. Model procesních nákladů sleduje výhradně náklady na procesy a činnosti s nimi spojené. Model nákladů na životní cyklus je používán v souvislosti s měřením a monitorováním nákladů u zákazníka. Tyto náklady definuje norma ČSN EN 60300-3-3. Vysoké náklady u zákazníka vedou $\mathrm{k}$ následné nespokojenosti, a proto je důležité, aby výrobci tyto náklady sledovali a na základě toho mohli rozhodovat o zlepšování. (Nenadál, 2004) 


\section{Zásady managementu kvality a metody $k$ jejich dosažení}

Pro zvyšování výkonnosti podniku bylo v ISO 9000:2005 identifikováno 8 zásad managementu kvality, které by měl vrcholový management využívat, a tyto byly uvažovány v dalším výzkumu tohoto př́spěvku. (Veber, 2007) Implementace zásad systému managementu kvality je obvyklá spíše ve velkých podnicích. U malých a středních podniků v důsledku omezení zdrojů a managementu nebývá implementace tak běžná. Výhodou malých firem při zavádění pak bývá naopak jednoduchá organizační struktura a malý počet zaměstnanců. (Duchková, 2012) V koherenci 8 zásad managementu kvality existuje celá řada procesů, které je nutno realizovat $\mathrm{k}$ dosažení požadavků implementací celé řady nástrojů a metod. Tyto nástroje a metody pomohou managementu odhalit problémy nebo možné př́ležitosti, naznačí cestu $\mathrm{k}$ řešení a přispívají tak $\mathrm{k}$ eliminaci ztrát. Je důležité evaluovat metody propojující management kvality s ekonomickými př́nosy pro podnik. $\mathrm{K}$ dosažení zásad managementu kvality musí podnik uskutečnit celou řadou procesů, při kterých využívá metody a nástroje zobrazené $\mathrm{v}$ tabulce 2 . Kvantifikovat své silné stránky a př́ležitosti, využít je pro posílení slabých stránek a hrozeb. Provést kritické sebehodnocení. Stanovit nejlepší parametry výkonnosti a metody $\mathrm{k}$ jejich dosažení. Podnik musí ale především využít proces zlepšování a učení se.

Tabulka 2: Zásady managementu kvality - procesy, nástroje a metody

\begin{tabular}{|c|c|c|}
\hline Zásada & Procesy & $\begin{array}{l}\text { Nejpoužívanější nástroje } \\
\text { a metody }\end{array}$ \\
\hline Zaměření na zákazníka & $\begin{array}{l}\text { - průzkum, analýza a hodnocení trhu, } \\
\text { - zkoumání požadavků zákazníků, } \\
\text { - rozvoj a řízení vztahu se zákazníkem, } \\
\text { - měření spokojenosti a loajality zákazníků. }\end{array}$ & - SWOT. \\
\hline Vedení a řízení lidí & $\begin{array}{l}\text { - strategické plánování, } \\
\text { - rozdělování odpovědností a pravomocí, } \\
\text { - interní a externí komunikace, analýza rizik. }\end{array}$ & - SWOT. \\
\hline Zapojení lidí & $\begin{array}{l}\text { - plánování lidských zdrojů, hodnocení, } \\
\text { - odhalování slabých míst ve výkonnosti, } \\
\text { - trvalé vzdělávání zaměstnanců, týmová práce. }\end{array}$ & $\begin{array}{l}\text { - SWOT, } \\
\text { - benchmarking. }\end{array}$ \\
\hline Procesní přístup & $\begin{array}{l}\text { - definice procesů, činností a vazeb, } \\
\text { - stanovení cílových hodnot ukazatelů, } \\
\text { - plánování procesů, přidělování zdrojů, } \\
\text { - monitorování a vyhodnocování ukazatelů } \\
\text { výkonnosti a zlepšování procesů. }\end{array}$ & $\begin{array}{l}\text { - SWOT, } \\
\text { - sebehodnocení. }\end{array}$ \\
\hline $\begin{array}{l}\text { Systémový př́ístup } \\
\text { k managementu }\end{array}$ & $\begin{array}{l}\text { - podrobný popis jednotlivých procesů, } \\
\text { deklarace vzájemné propojenosti v příručkách, } \\
\text { - stanovení cílů, analýza a řízení rizik, } \\
\text { - hodnocení výkonnosti systému. }\end{array}$ & - sebehodnocení. \\
\hline Neustálé zlepšování & $\begin{array}{l}\text { - identifikace příležitostí ke zlepšování, použití } \\
\text { vhodné metodologie, sledování a hodnocení } \\
\text { výsledků, zajišt'ování zdrojů pro zlepšování, } \\
\text { - sběr a analýza informací, navrhování řešení. }\end{array}$ & $\begin{array}{l}\text { - benchmarking, } \\
\text { - sebehodnocení. }\end{array}$ \\
\hline $\begin{array}{l}\text { Přístup k rozhodování } \\
\text { zakládající se na faktech }\end{array}$ & $\begin{array}{l}\text { - sběr přesných a spolehlivých dat jednotlivých } \\
\text { procesů v čase, vhodná analýza dat na základě } \\
\text { procesů měření výsledků, využívání vhodných } \\
\text { statistických nástrojů a vyhodnocování dat. }\end{array}$ & - SWOT. \\
\hline $\begin{array}{l}\text { Vzájemně prospěšné } \\
\text { dodavatelské vztahy }\end{array}$ & $\begin{array}{l}\text { - výběr strategicky významných dodavatelů, } \\
\text { - pravidelné hodnocení dodavatelů, } \\
\text { - komunikace a motivace ke zlepšování, pružná } \\
\text { reakce dodavatelů, stanovení kritérií. }\end{array}$ & $\begin{array}{l}\text { - SWOT, } \\
\text { - benchmarking. }\end{array}$ \\
\hline
\end{tabular}

Zdroj: vlastní zpracování dle Hoyle (2009)

Primárním šetřením, jehož výsledky jsou uvedeny níže, bylo zjištěno, že u zkoumaných podniků se řadí mezi nejpoužívanější metody SWOT analýza, benchmarking a metoda 
sebehodnocení (viz tabulka 2). Prvním krokem je situační analýza, jejímž vyústěním je SWOT analýza zohledňující externí a interní analyzované faktory podniku. Poté pro zlepšení slabých stránek a hrozeb pomocí benchmarkingu procesem učení se aplikuje nejlepší praktiky od konkurence. Pravidelným sebehodnocením pak podnik kontroluje dodržování plánu hodnocení podniku a následnou realizaci projektu zlepšování.

SWOT analýza je nástrojem pro analýzu klíčových faktorů ovlivňujících strategické postavení podniku. Při analýze je identifikována vnitřní situace (silné a slabé stránky) a vnější okolí podniku (př́ležitosti a rizika). Základním smyslem analýzy je rozvíjet silné stránky, potlačovat ty slabé a být současně připraven na potenciální prŕíležitosti a hrozby. (Sedláčková, 2006) Silné stránky charakterizují interní faktory, představují oblasti, ve kterých má podnik dobré schopnosti, dovednosti, možnosti zdrojů a potenciálu. Slabé stránky prezentují nedostatky podniku bránící efektivnímu výkonu. Příležitosti kvantifikují možnosti růstu, využití zdrojů a účinné plnění cílů. Hrozby charakterizují nepříznivé okolí podniku znamenající překážky v činnosti podniku. (Blažková, 2007) Cílem je identifikovat schopnost podniku vyrovnat se změnám okolí a kvantifikovat relevantnost podnikové strategie a jejích slabých a silných míst. Aby měla SWOT analýza pro podnik význam, musí být zaměřena na ekonomiku. Výsledky přispějí ke zlepšení výkonnosti podniku na základě řešení reagující na skutečné př́ićiny. Kvalita má ke SWOT analýze účinnou vazbu, nebot' kvalita výrobků a služeb tvoří jednu z hlavních silných stránek podniku, nicméně může být i slabou stránkou podniku. Kvalita rozhodně tvoří pro podnik řadu prríležitostí, např́klad zlepšováním výrobků a služeb a zvyšováním spokojenosti zákazníka. Je však nutno zmínit, že kvalita může být zároveň i hrozbou, pokud se nedaří úspěšně dodržovat nastavené cíle v oblasti kvality, př́ípadně ještě kvalitu zvyšovat. Rovněž tak získání certifikace managementu kvality a jeho zavedení a aplikace $\mathrm{v}$ podniku je možnou př́ležitostí podniku. Naopak neshody výrobků, nespokojenost a neplnění požadavků zákazníků mohou být slabou stránkou a do budoucna tvoři hrozby podniku, které je potřeba sledovat. Tyto hrozby mohou negativně ovlivnit ekonomické výsledky podniku a v krajním př́ípadně mohou být i likvidační. Provedení SWOT analýzy může být předpokladem pro aplikaci a dosažení zásad managementu kvality

Benchmarking je proces, při kterém se porovnávají a měří procesy, produkty, činnosti a metody podniku především s ostatními konkurenčními podniky. Snahou podniku při aplikaci porovnávání a měření je učení se a zlepšování. Benchmarking je realizován ve čtyřech základních etapách: Plánování $\Rightarrow$ Sběr dat $=>$ Analýza nasbíraných dat $=>$ Realizace stanovených opatření. (Fotr, 2012) Také benchmarking je úzce spojen s aplikací zásad managementu kvality. V procesu učení se od ostatních podnik využije při aplikaci zvyšování výkonnosti úsporu času, nákladů a redukci neefektivnosti. V důsledku využití nejlepších postupů od konkurence dochází ke zlepšování kvality výrobků a služeb či procesů a tím dochází i ke snižování nákladů na nízkou kvalitu a na prevenci.

Sebehodnocení podniku je pravidelné a systematické hodnocení interních procesů a výsledků. Podniku umožňuje poznat svoje silné a slabé stránky a zaměřit se tak účelně na oblasti pro zlepšování. Tato metoda slouží především pro manažery kvality. Zohledňuje požadavky zákazníků a rozvíjí zásady managementu kvality.

Postup sebehodnocení:

- dosažení shody o sebehodnocení - shoda mezi členy vrcholového vedení podniku o účelnosti a potřebě sebehodnocení,

- zpracování plánu sebehodnocení,

- stanovení týmu pro sebehodnocení a jeho výcvik,

- vysvětlení plánu sebehodnocení - výběr metody sebehodnocení a vypracování konečné verze plánu sebehodnocení,

- realizace sebehodnocení vybranou metodou - výstupem by měl být seznam př́ležitostí ke zlepšování, neboli seznam slabých stránek podniku. 
Pokud má mít metoda sebehodnocení význam pro aktivní řešení problémů podniku, musí celý systém pokračovat procesem zlepšování ve třech fázích (Nenadál, 2004):

- zpracování plánu projektu zlepšování,

- realizace projektu zlepšování,

- přezkoumání účinnosti projektu zlepšování.

Důležitou součástí sebehodnocení je zhodnocení plnění kritérií a požadavků zvoleného modelu. Ke kvantifikaci výsledků sebehodnocení může podnik využít vlastní vytvořenou metriku nebo použít doporučované způsoby kvantifikace, např́íklad logické schéma RADAR. Hodnocení logickým schématem RADAR vychází z presumpce, že naplánování a vhodný výběr metod a postupů, jejich uplatnění $\mathrm{v}$ celém podniku a systematické hodnocení s následným cílem zlepšování jsou základním předpokladem pro dosažení pozitivních výsledků. Každý posuzovatel má k dispozici schéma a hodnotí jednotlivá dílčí kritéria podle předem dohodnuté škály, hodnocení je $\mathrm{v} \%$. Ke každému procentnímu ohodnocení se přiřadí váha kritéria a výsledky hodnocení zjistí posuzovatelé na základě skóringového součtu pomocí sumarizační tabulky. Tabulka 3 obsahuje návrh na vyhodnocovací tabulku metody RADAR. Kritéria jsou určená v korelaci ke kvalitě. (Nenadál, 2004)

Tabulka 3: Vyhodnocovací sumarizační tabulka metody RADAR

\begin{tabular}{|l|l|l|l|}
\hline Kritérium & \% & Váha kritéria & Skóringový součet \\
\hline Vedení & & & \\
\hline Politika a strategie & & & \\
\hline Lidé & & & \\
\hline Partnerství a zdroje & & & \\
\hline Procesy & & & \\
\hline $\begin{array}{l}\text { Výsledky vzhledem k } \\
\text { zákazníkúm }\end{array}$ & & & \\
\hline Klíčové výsledky kvality & & & \\
\hline Celkem bodů & & & \\
\hline
\end{tabular}

Zdroj: vlastní zpracování dle Nenadál (2004)

Předpokladem aplikace metodiky RADAR je stanovení cílů, ke kterým jsou přiřazeny měřitelné ukazatele a aktivity pomocí kterých bude dosahováno stanovených cílů. Tyto př́istupy jsou následně hodnoceny a dosahované ukazatele poskytují podniku zpětnou vazbu.

\section{Výsledky primárního šetření}

Primární šetření zahrnovalo vytvoření výzkumného vzorku podniků, u kterých bylo provedeno. Prvním kritériem pro výběr daného podniku bylo, zda podnik má v organizační struktuře zakotvenu funkci manažera kvality. Z tohoto důvodu se výběr zúžil na střední a velké podniky. Dalším kritériem bylo zaměření činnosti podniku, kdy cílem bylo zkoumat výrobní podniky, nebot' jedním ze zkoumaných ukazatelů byla kvóta kvality, která je u zkoumaných podniků kvantifikována. Pro vyčíslení kvóty kvality využívá každý podnik svoji metodiku výpočtu, nicméně obecně se jedná o podíl celkového počtu zachycených chyb (vadných výrobků) za měsíc a celkového počtu zkontrolovaných výrobků. Kvóta kvality neboli rovněž chybovosti se porovnává měsíčně a pak se sleduje kumulace celého roku. Následně dochází k meziroční komparaci. Dle zjištěných hodnot pak podnik evaluuje v jednotlivých měsících zhoršení či zlepšení a pak sleduje rovněž vývoj meziročně (zlepšení, zhoršení, stagnace). Pro kvantifikaci a sledování kvóty kvality je nutno v podniku určit, jaký podíl produkce bude kontrolován. Poslední kritérium pro výběr bylo provádění každoročního hodnocení kvality formou zjištování chybovosti v absolutním i relativním vyjádření. Výzkumný vzorek sestával z 34 velkých podniků a 16 středních podniků a zahrnoval podniky z oblasti automobilového průmyslu, strojírenství, kovovýroba, papírenská výroba apod. Všechny ze zkoumaných podniků mají více než 250 zaměstnanců. 
Strukturované rozhovory ve vybraných podnicích byly vedeny s manažery kvality, finančními řediteli a vedoucími pracovníky ve výrobě. Dále byly využity metoda pozorování a dotazování. Primární šetření bylo realizováno v měsících záŕí, říjen, listopad a prosinec roku 2015. Cílem primárního šetření bylo identifikovat vývoj kvality dle kvóty kvality ve vybraných podnicích, zjistit, zda vybrané podniky aplikují 8 zásad managementu kvality a v jakém rozsahu. Dílčím cílem bylo určit vztah mezi kvalitou a mírou fluktuace. Dalším dílčím cílem bylo zjistit, zda podniky sledují náklady na kvalitu.

V prvním kroku výzkumu byl u sledovaných podniků zjišt’ován vývoj kvality v dlouhém období (identifikace trendu). Bylo sledováno, zda trendem je spíše zlepšování nebo zhoršování či zda je vývoj kvality na konstantní úrovni. Jak demonstruje obrázek 1, 36 zkoumaných podnikatelských subjektů $(60 \%)$ vykazuje zlepšující se trend, kdežto oproti tomu u 4 (přibližně $7 \%$ ) byl identifikován trend zhoršování. 20 podniků (přibližně $33 \%$ ) vykazuje konstantní úroveň kvality v desetiletém časovém horizontu. Historický vývoj kvality podniků byl zkoumán $\mathrm{z}$ důvodu jeho významné vypovídací schopnosti o úspěšnosti a efektivním řízení firmy. Zlepšení či zhoršení bylo určeno dle vývoje ukazatele kvóty kvality, kdy vyšší hodnota ukazatele kvóty kvality znamenala zhoršení a nižší kvalita znamenala zlepšení. Za konstantní úroveň se dle provedeného primárního šetření ve vybraných podnicích považuje kolísání ukazatele kvality v intervalu $0-0,05 \%$.

Obrázek 1: Vývoj kvality v dlouhém období

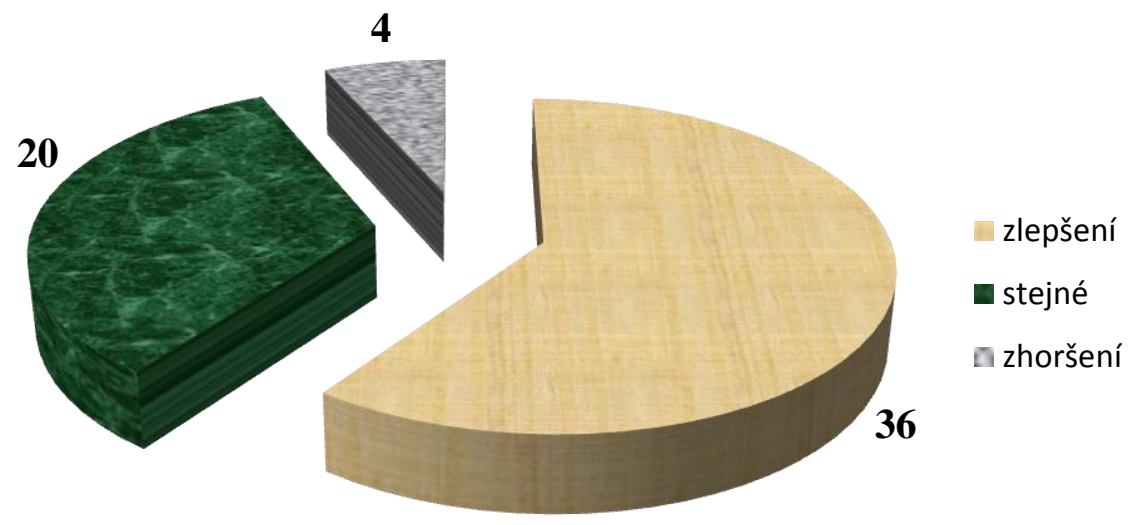

Zdroj: vlastní výzkum (2015)

Další (druhý) krok výzkumu zahrnoval zjišstování, zda zkoumané podniky aplikují 8 zásad managementu kvality (uvedených $v$ tabulce 2), nebot' respektování těchto zásad významně přispívá k optimalizaci kvality podnikatelského subjektu. Šetřením bylo identifikováno, že 28 podniků (přibližně $47 \%$ ) respektuje při řízení tyto zásady, kdežto oproti tomu 8 podniků (přibližně $13 \%$ ) je nebere v potaz. Ćástečná aplikace 8 zásad managementu kvality byla zjištěna u 24 podniků (40 \%). Výsledky jsou graficky ilustrovány v obrázku 2. 
Obrázek 2: Aplikování 8 zásad managementu kvality v podniku

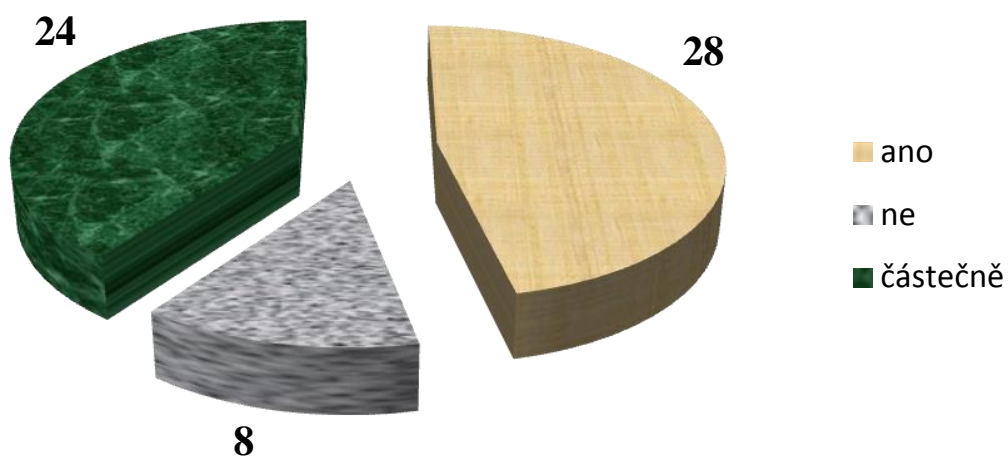

Zdroj: vlastní výzkum (2015)

Metodou pozorování, dotazování i formou rozhovoru byla ve třetím kroku výzkumu zjišt’ována úroveň realizace jednotlivých nástrojů a metod zobrazených $\mathrm{v}$ tabulce 2 pro dosažení zásad managementu kvality. Jak uvádí tabulka 4, 16 ze zkoumaného souboru podniků (přibližně $27 \%$ ) nepouživá žádnou z výše uvedených metod, 24 podniků (přibližně $40 \%$ ) využívá $1-2$ metody (SWOT a benchmarking) a 16 podniků (přibližně 27 \%) využívá 3 - 4 metody (SWOT, benchmarking, sebehodnocení a dále navíc Failure Mode and Effects Analysis procesu). Pouze 4 podniky (přibližně $7 \%$ ) využívají 5 a více metod pro zvyšování kvality (SWOT, benchmarking, sebehodnocení, mimo uvedených metod v tabulce 2 se dále jedná o Failure Mode and Effects Analysis procesu, Six Sigma, brainstorming, rrízení vztahů se zákazníky). V návaznosti na velikost a typ podnikatelského subjektu by měl vrcholový management ve spolupráci se středním managementem určit, jaké metody jsou stěžejní pro zlepšování kvality a tyto implikovat. Implikace jednotlivých metod je potřeba zhodnotit z hlediska nákladovosti a provést realizaci v souladu s efektivním řízením podniku.

Tabulka 4: Realizace nástrojů a metod zásad managementu kvality

\begin{tabular}{|l|l|l|l|l|}
\hline $\begin{array}{l}\text { Úroveň realizace } \\
\text { nástrojů a metod zásad } \\
\text { managementu kvality }\end{array}$ & $\begin{array}{l}\text { Nepoužívá } \\
\text { žádnou metodu }\end{array}$ & Použití 1-2 metody & Použití 3-4 metod & $\begin{array}{l}\text { Použití } 5 \text { a více } \\
\text { metod }\end{array}$ \\
\hline Počet podnikú & 16 & 24 & 16 & 4 \\
\hline
\end{tabular}

Zdroj: vlastní výzkum (2015)

Čtvrtý krok výzkumu byl zaměřen na problematiku fluktuace zaměstnanců. Doporučovaná hodnota míry fluktuace je $5-10 \%$, ve všech sledovaných podnicích byla ovšem míra fluktuace vyšší než $12 \%$, což koresponduje se současným vývojem nezaměstnanosti na trhu práce a nedostatkem pracovních sil (viz tabulka 5). Vývoj na trhu práce přispívá $\mathrm{k}$ růstu fluktuace pracovníků $\mathrm{v}$ podnicích. Existuje několik opatření pro omezení fluktuace pracovníků, které by měly být $\mathrm{v}$ podnikatelském sektoru analyzovány. Jedná se zejména o výši mzdy, pracovní prostředí, image firmy, nefinanční složky odměňování apod. Ve zkoumaných podnikatelských subjektech bylo dotazníkovými šetřeními (prováděné personálními odděleními) zjištěno, že nejvyšší váhu přikládají zaměstnanci výši mzdy. Na základě nákladové analýzy by v podnicích mělo být zkoumáno, zda je možné provést navýšení mezd, aby nebylo ohroženo efektivní fungování subjektu. Dílčími podklady by měly být např́klad i údaje z okolí podniku (situace na trhu práce apod.). 
Tabulka 5: Míra fluktuace v jednotlivých podnicích

\begin{tabular}{|l|l|l|l|l|}
\hline Míra fluktuace & $\mathbf{1 2}-\mathbf{1 5} \%$ & $\mathbf{1 6}-\mathbf{2 0} \%$ & $\mathbf{2 1}-\mathbf{2 5} \%$ & $\mathbf{2 6}-\mathbf{2 9} \%$ \\
\hline Počet podniků & 24 & 16 & 16 & 4 \\
\hline
\end{tabular}

Zdroj: vlastní výzkum (2015)

Předmětem sledování ve čtvrtém kroku výzkumu byla i souvislost zvýšené míry fluktuace a vývojem kvóty kvality v podniku v krátkém období. Zjišt'ováním bylo identifikováno (viz tabulka 6), že fluktuace zaměstnanců výrazně souvisí s ukazatelem kvóty kvality (kvantifikace je provedena jako počet chyb v poměru ke zpracovaným výstupům neboli produktům, postup výpočtu je uveden výše). Z tohoto důvodu je fluktuace považována za významný negativní jev pro chod a dlouhodobou prosperitu podnikatelských subjektů. V podnicích, jejichž míra fluktuace dosáhla dle provedeného šetření míry $28 \%$, bylo evaluováno zhoršení kvóty kvality o více než 90 \% (postup kvantifikace kvóty kvality byl uveden výše).

Tabulka 6: Vývoj kvality v závislosti na míře fluktuace

\begin{tabular}{|l|l|l|l|}
\hline Vývoj kvality & Zlepšení kvality & Stejné hodnoty kvality & Zhoršení kvality \\
\hline Počet podniků & 0 & 24 & 36 \\
\hline
\end{tabular}

Zdroj: vlastní výzkum (2015)

Metodou dotazování bylo v pátém kroku výzkumu zjišstováno, zda podnik sleduje náklady vynaložené v souvislosti s kvalitou, zda vede operativní evidenci nákladů, kde jsou tyto náklady kvantifikovány a zda jsou sledovány všechny náklady na neshody a prevenci zobrazené v tabulce 1, kdy šetření prokázalo, že 28 podniků (přibližně $47 \%$ ) nesleduje tyto náklady. Všechny náklady vynaložené na kvalitu nesleduje žádný ze zkoumaných podniků a částečné sledování je prováděno pouze v $8 \mathrm{z}$ výzkumného vzorku podniků (přibližně $13 \%$ ). Nejčastěji je sledována fluktuace, což bylo identifikováno u 24 zkoumaných podnikatelských subjektů (40\%). Výsledky, zda podnik sleduje náklady na kvalitu, jsou znázorněny v tabulce 7. Součástí tohoto kroku výzkumu bylo absolutní zjišt’ování, zda podnikatelské subjekty zahrnuté ve výzkumném vzorku vedou operativní evidenci nákladů na kvalitu. Většina ze zkoumaných podniků tuto evidenci nevede. Zda podnik vede nebo nevede operativní evidenci nákladů na kvalitu, znázorňuje obrázek 3.

Tabulka 7: Sledování nákladů vynaložených na kvalitu

\begin{tabular}{|l|l|l|l|l|}
\hline $\begin{array}{l}\text { Úroveň sledování nákladů } \\
\text { na kvalitu }\end{array}$ & Nesleduje & Sleduje pouze fluktuaci & Sleduje částečně & $\begin{array}{l}\text { Sleduje všechny } \\
\text { náklady }\end{array}$ \\
\hline Počet podniků & 28 & 24 & 8 & 0 \\
\hline
\end{tabular}

Zdroj: vlastní výzkum (2015)

Ze zjištěných informací plyne závažný závěr, kdy podnikatelské subjekty by měly z důvodu optimalizace fungování podniku sledovat alespoň zásadní náklady na kvalitu, nikoli pouze fluktuaci. Jedná se o sledování nákladů vynaložených na prevenci (školení, předcházení chybám), sledování (kontrola, zkoušení, včasné nalezení chyb), náklady na opravu chybných výrobků. Po jejich kvantifikaci by mělo být provedeno zhodnocení a navržena opatření pro snížení až eliminaci. 
Obrázek 3: Operativní evidence nákladů na kvalitu

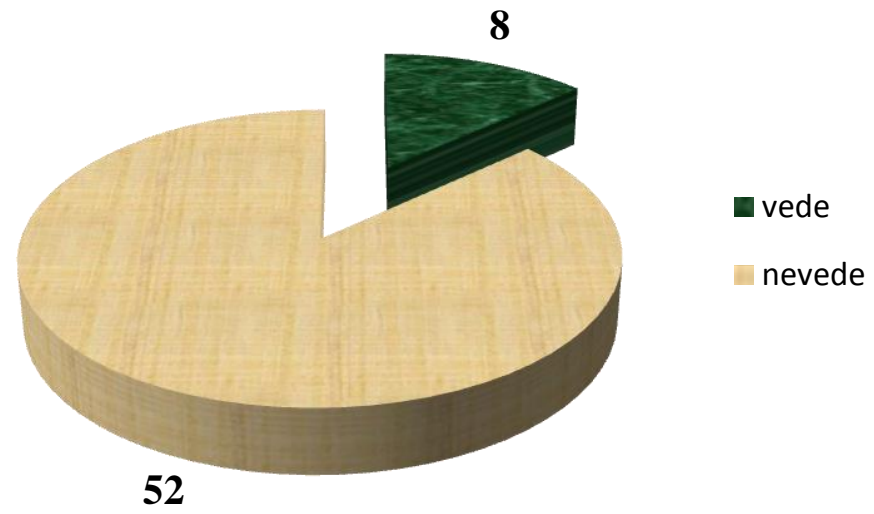

Zdroj: vlastní výzkum (2015)

\section{Závěr}

Jak bylo objasněno, kvalita výrobků a služeb, procesů a zdrojů je stěžejním faktorem pro fungování podniku, a to z důvodu její úzké provázanosti sekonomickými výsledky podnikatelského subjektu. Především ve středních a velkých podnicích by měly být koncipovány a sledovány ukazatele kvality. Sledování by mělo být realizováno nejen izolovaně $\mathrm{v}$ jednotlivých rocích, nýbrž i v časových řadách, ze kterých lze určovat trendy. Významnost kvality v podniku podtrhuje aspekt, že se jedná o klíčový faktor budování loajality zákazníka k firmě, nebot' kvalita má bezprostřední vliv na jeho spokojenost. Význam řízení kvality je zvýšen současnou vysokou orientací na zákazníka. Ve zkoumaných podnicích je nutno stanovovat cíle v oblasti kvality a tyto zapracovávat do podnikových strategií. Cíle musí být jasně určeny a musí být měřitelné a kontrolovatelné. Neméně důležitým faktorem pro budování kvality v podniku je motivace zaměstnanců, což se dle provedeného výzkumu jeví jako nejsložitější část tohoto procesu. Při řízení kvality lze vycházet z 8 zásad managementu kvality a predevším ve velkých podnicích by mělo být cílem tyto zásady respektovat. Úspěšné řízení kvality v podniku se neobejde bez sledování nákladů na kvalitu, především náklady na fluktuaci zaměstnanců.

$\mathrm{Na}$ základě provedeného výzkumu ve středních a velkých podnicích bylo zjištěno, že v dlouhém období dochází k postupnému zlepšování kvóty kvality a je to nepochybně v souvislosti s využíváním zásad managementu kvality. Doporučení pro všechny sledované podniky je využití celé řady metod a nástrojů pro podporu zásad managementu kvality. Metody sebehodnocení, srovnávání a učení se zajisté přispějí ke zlepšení kvality. Využít $\mathrm{k}$ tomu lze metod benchmarkingu a sebehodnocení. SWOT analýza napomůže odhalení silných a slabých stránek v oblasti kvality a v procesech, které jsou s kvalitou úzce propojeny. Metoda Failure Mode and Effects Analysis procesu přispěje k odhalení a definování všech selhání, jejich prŕíčin a důsledků během celého procesu. Pro identifikaci nápravných opatření a možností zlepšení aplikovat techniku brainstormingu. Pro identifikaci a odstranění prř́čin chyb v procesech mohou podniky implementovat metodu Six Sigma. V současné době dochází u sledovaných podniků ke zhoršení kvality v krátkém období v důsledku zvyšující se fluktuace zaměstnanců. Doporučením je sledovat pravidelně míru fluktuace, zaměřit se na kvalitní proškolení nových zaměstnanců, provést př́padně reengineering zaškolování. Cílem by bylo zamezit $\mathrm{v}$ co nejvyšší míře důsledkům rotujících zaměstnanců na kvalitu, nebot' rotace zaměstnanců omezuje jejich specializaci a tím přispívá ke zhoršení kvality. Při úvaze o reengineeringu zaškolování je nutno zohlednit náklady s tím související a zvážit efektivitu tohoto opatření. Dalším doporučením je podporovat aspekty zvyšující motivaci zaměstnanců a posilující jejich loajalitu vůči podniku. Většina sledovaných podniků nekvantifikuje náklady spojené s kvalitou a nevede operativní evidenci těchto nákladů. Doporučením pro podniky je 
kvantifikovat pravidelně všechny náklady na neshody i na prevenci a zaznamenávat tyto náklady do operativní evidence. Po vyčíslení nákladů na neshody a na prevenci je potřeba, aby management podniku na vznik těchto nákladů reagoval a snažil se je co nejvíce $\mathrm{v}$ budoucnu eliminovat. Eliminace těchto negativních důsledků poté přispívá ke zvyšování hospodárnosti a celkové efektivity organizace, která se neprojevuje jen v podobě prvotních kvantifikovatelných měřítek např́klad v podobě nákladů, ale rovněž v podobě spokojenosti zákazníků, u nichž pak dochází k budování vztahu s podnikem.

\section{Poděkování}

Tento prŕspěvek byl zpracován za podpory projektu SGS-2015-019 Dopady aktuálních právních, daňových, účetních a sociálních změn na soukromé podniky a veřejný sektor v kontextu rekodifikace soukromého práva.

\section{Literatura}

[1] BLAŽKOVÁ, M., 2007. Marketingové ř́zení a plánování pro malé a střední firmy. Praha: Grada. ISBN 978-80-2471-535-3.

[2] DUDA, J. a L. ŽŮRKOVÁ, 2014. Definování matematických vzorců při zjištování nákladů u fluktuace pracovníků v podniku. Acta academica karviniensia, 14(2), 14-21, ISSN 1212-415X.

[3] DUCHKOVÁ, V. a I. HOFMAN, 2012. Specifika managementu kvality v malém stavebním podniku. Trendy v podnikání, 4(2), 47-56. ISSN 1805-0603.

[4] FOTR, J., E. VACÍK a kol., 2012. Tvorba strategie a strategické plánování: Teorie a praxe. Praha: Grada. ISBN 978-80-247-3985-4.

[5] HOYLE, D., 2009. ISO 9000 Quality Systems Handbook: Using the Standards as a Framework for Business Improvement. Routledge. ISBN 978-18-5617-684-2.

[6] JÁČ, I., J. SEDLÁŘ a kol., 2013. Principles of creating a cost-cutting strategy a tan enterprise by means of the Lean production concept. Ekonomie a Management, E + M., 16(3), 75-84. ISSN 1212-3609.

[7] LINß, G., 2011. Qualitätsmanagement für Ingenieure. Leipzig: Fachbuchverlag. ISBN 3446-21763-0.

[8] ManagementMania, 2011-2013. Manažer kvality (Quality Manager). ManagementMania [online]. 24. prosinec 2015. Dostupné z: managementmania.com/cs/manazer-kvality

[9] NENADÁL, J., 2004. Měrení v systémech managementu jakosti. Praha: Management Press. ISBN 80-7261-110-0.

[10] NENADÁL, J. et al., 2008. Moderní management jakosti: principy, postupy, metody. Praha: Management Press. ISBN 978-80-7261-186-7.

[11] PLÁS̆KOVÁ, A., 2004. Jednoduché nástroje řizení jakosti II. Praha: Národní informační středisko pro podporu jakosti. ISBN 80-02-01690-4.

[12] SEDLÁC̆KOVÁ, H. a K. BUCHTA, 2006. Strategická analýza. Praha: C. H. Beck. ISBN 978-80-7179-367-0.

[13] SUCHÁNEK, P. a M. KRÁLOVÁ, 2014. Model vlivu spokojenosti zákazníka na výkonnost podniku. Trendy v podnikání, 4(3), 40-46. ISSN 1805-0603.

[14] ŠTAMFESTOVÁ, P., 2013. Vztah kvality a zákaznického kapitálu. Trendy v podnikání, 4(3), 80-87. ISSN 1805-0603. 
[15] VEBER, J. a kol., 2007. Řizení jakosti a ochrana spotřebitele. Praha: Grada. ISBN 97880-247-1782-1.

[16] VEBER, J. a kol., 2010. Management kvality, environmentu a bezpečnosti práce: legislativa, systémy, metody, praxe. Praha: Management Press. ISBN 978-80-7261-2109.

[17] ZVONEČEK, F. a H. ZÍDKOVÁ, 2001. Jakost - styl života pro třetí tisíciletí. Plzeň: ZČU v Plzni. ISBN 80-7082-720-3. 